\title{
BM] Global Health Powerful ideas? Decolonisation and the future of global health
}

\author{
Mark Hellowell (D) , ${ }^{1}$ Patricia Nayna Schwerdtle (D) ${ }^{2}$
}

To cite: Hellowell M, Nayna Schwerdtle P. Powerful ideas? Decolonisation and the future of global health. BMJ Global Health 2022;7:e006924. doi:10.1136/ bmjgh-2021-006924

Received 19 July 2021 Accepted 30 September 2021

Check for updates

C) Author(s) (or their employer(s)) 2022. Re-use permitted under CC BY-NC. No commercial re-use. See rights and permissions. Published by BMJ.

${ }^{1}$ Global Health Policy Unit, School of Social and Political Science, University of Edinburgh, Edinburgh, UK

${ }^{2}$ Heidelberg Institute of Global Health (HIGH), Faculty of Medicine and University Hospital, Heidelberg University, Heidelberg, Germany

Correspondence to Dr Mark Hellowell; mark.hellowell@ed.ac.uk

\section{INTRODUCTION}

Calls to 'decolonise' global health have intensified in recent years, as reflected in the rapid growth of the academic literature on this concept. ${ }^{1-6}$ This body of work (henceforth: 'the literature') draws on the conceptual frameworks and interpretive lenses of Critical Race Theory and related analyses of structural racism in Western countries ${ }^{78}$ alongside postcolonial theory and related analyses of colonialism's cultural, psychological and material impacts and legacies, especially in the 'Global South'. 910 The literature calls attention to asymmetries in the distribution of epistemic authority and decisionmaking power in global health and argues that these have their origins in colonialism and continue to advantage and empower some persons over others, depending on their race, ethnicity and place of origin with the disadvantaged group comprising Indigenous communities and ethnic minorities in the 'Global North', and black people and people of colour in the 'Global South'. ${ }^{11} 12$

There is a range of different arguments about the best methods for addressing these asymmetries. Authors affiliated to the Global Health Decolonisation Movement in Africa emphasise the urgency of the need for change, and argue for reforms that are discrete, tangible and measurable. ${ }^{13}$ Others make the case for deeper, more systemic, and perhaps more ambiguous approaches to reform-including, in the case of one article, the 'complete overhaul' of global health, including 'removal of the coloniser' from the discipline. ${ }^{14}$ Despite these differences, a number of analytical tendencies are common across the literature, three of which provide our focus in this commentary. These relate to: knowledge (the argument that global health favours 'Western' forms of knowledge and marginalises others); universalism (the argument

\section{Summary box}

Calls to 'decolonise' global health have intensified in recent years, as reflected in the rapid growth of the academic literature on this concept. Despite its increasing prominence, this literature has not been critically assessed.

- Our assessment focuses on three tendencies in this literature-which relate to knowledge, universalism and purpose in global health. We consider the implications of these tendencies for the future of the discipline and its ability to deliver worldwide improvements in health.

- We argue that the decolonisation agenda has the potential to stimulate a needed redistribution of decision-making power in global health.

- Yet, we also identify a number of potential harmsby undermining confidence in scientific knowledge; accentuating inter-group and international antagonisms; and curtailing the opportunies for redistributive change in the future.

that global health is defined by a 'Eurocentric' conception of humanity which is incomplete, partial and unjust); and purpose (the argument that the purportedly colonial origins of global health are retained in the contemporary structures and practices of the field).

In this commentary, we define 'global health' as an endeavour that aims at the worldwide improvement of health; and 'global health institutions' as the entities primarily concerned with advancing this aim. We recognise that the decolonialist critique has the potential to stimulate a redistribution of epistemic authority and decision-making power in global health and by doing so enhance its potential to 'do good'. But we have also identified a number of potential harms, by: (i) undermining confidence in scientific knowledge; (ii) accentuating inter-group and inter-national antagonisms; and (iii) by discounting the degree of progress already achieved that may curtail opportunities for redistributive change in the future. 


\section{KNOWLEDGE}

We observe two related but distinct arguments in the literature concerning knowledge and its uses in global health. First is the claim that knowledge held by persons in, or from, the 'Global South' is inadequately respected in the discipline, and is therefore not properly represented in decision-making. ${ }^{15} 1617$ As global health scholars and practitioners, we are aware that 'local' expertise - expertise held by persons close to the problems being considered and the contexts in which they exist - generally has a lower standing than 'international' expertise. Often, there is no justification for this asymmetry, and the most beneficial insights and policies arise from combining the best propositional and experiential knowledge from whatever source. Given this, any marginalisation of 'Southern' knowledge (ie, that which is reflective of local expertise, structures, norms and preferences) can only reduce the discipline's effectiveness. ${ }^{18}$ The attempt by decolonialist scholars to bring additional attention to this problem is valuable, even if it is not unique to this mode of analysis.

However, we also observe a second less compelling claim that different 'ways of knowing' exist across different groups - that there are forms of knowledge and knowledge formation that belong to white, Western persons (oppressors), and forms that belong to others (the oppressed). ${ }^{19}$ The higher status afforded to the former over the latter is, then both a source and a result of injustice. It is argued in this vein that the emphasis placed on 'research-based knowledge' over 'lived experience' is unjust, and serves to establish, deepen and entrench asymmetries. ${ }^{5}$ In extensions of this analysis, the legitimacy of whole fields are questioned. For example, the discipline of epidemiology is cast as one in which 'bourgeois empiricists' build 'fable models', based on assumptions 'conjured from the standpoint of dominant interests...(to) conceal violently seized privilege'; and is therefore 'in clear need of decolonising'. ${ }^{20}$

In our view this argument is far-fetched and unhelpful. It is demeaning to researchers or technical experts assigned to the 'oppressed' category, and corrosive of their ability to achieve beneficial impact ${ }^{21}$ Global health goals are undermined when valid claims to scientific knowledge and technical expertise are questioned or dismissed. This serves the interests of science denialists, political opportunists and those that seek to distract populations away from government failure and its consequences. During the current COVID-19 pandemic, as in previous pandemics, some governments have sought to undermine Western knowledge - including under the guise of decolonisation - in an attempt to head off criticism and to generate support for expedient but ineffective policies. ${ }^{22}$

\section{UNIVERSALISM}

The literature offers a critique of 'universalism' - the concern for others without regard to their race, ethnicity or geographical origin. In some instances, inter-group and/or international relationships are cast as inherently adversarial: there are 'the oppressors' that act in concert with each other in opposition to 'the oppressed'. Persons are assigned to these categories - 'oppressors' and 'oppressed' - according to aspects of their identity, especially race, ethnicity and geographical origin, while other forms of difference, such as age, income, or class are de-emphasised, if they are considered at all. The motivations, behaviours and actions of individuals can best be understood with reference to the interests of their specific identity group.

In one article, the notion of humanity itself is argued to be problematic, being 'inextricably linked to the Eurocentric conception of the (hu)man'. To deliver change, decolonisation has to begin with 'a deconstruction and dismantling of the concept of humanity as currently conceived, the uncoupling of Man from human and the unsettling of the hegemonic western universalist conception of the human, which normalises and over-represents the (western bourgeois) Man'. ${ }^{23}$ In another article, it is argued that 'descendants of colonialists' are 'morally unrelated' to those they are exploiting, being 'supporters of and beneficiaries from a global institutional order that systematises oppression'. ${ }^{24}$

These arguments conflict with the universalist ideal, in which all persons are held to be deserving of equal moral consideration, and which has always been core to global health - to enable - in Sen's words, the 'free(dom) from escapable illness, avoidable afflictions and premature mortality' for all. ${ }^{25}$ This is the foundation of global treaties such as the International Covenant on Economic, Social and Cultural Rights, which require signatory states to ensure non-discrimination in realising all persons' rights to health. It is also congruent with long-standing humanitarian principles, such as the commitment to assist all people in distress based on their need, and irrespective of race, religion or politics. These ideals call on global society to build on and strengthen inter-group and international solidarity, and do so by appealing to what is best in the nature of human beings; their sense of empathy, solidarity and fairness; and by overcoming what is deficient; the tendency towards resentment, venality and competitiveness. We imperil global health goals when we place these ideals in doubt.

\section{PURPOSE}

Like all complex social endeavours, global health is imperfect - in its design, implementation and impact. The field often fails to live up to its ideals and even its stated obligations and commitments. At the time of writing, young, healthy people in upper-middle and high-income countries are being de facto prioritised for COVID-19 vaccination above elderly, vulnerable people and health workers in low-income and lower-middle-income countries. This is an historic failure of the global health endeavour-or, perhaps more accurately, of the global economic order in which it is embedded. 
However, it is not clear that 'coloniality' is the cause of this and other failures - and this is not a trivial point. It matters because if we misdiagnose the causes of our problems we will pursue the wrong solutions or depress ourselves into a state of inaction. Understandably, the decolonisation literature has a strong focus on historical legacies - especially the continuities between past and present-day oppressions. For instance, one article notes, 'Ours is a discipline that holds within itself a deep contradiction - global health was birthed in supremacy, but its mission is to reduce or eliminate inequities globally'. ${ }^{12}$ However, even if some (surely, not all) global health institutions were founded during a period of territorial colonialism, it does not follow that "pervasive remnants of supremacy' must persist, nor that this is the best explanation for current problems. It is not self-evident that the evolution in the global health 'mission' - from supporting colonialism, to supporting health and reducing health disparities - is best understood in terms of strategic confusion. It might instead be taken as evidence of progress.

In the context of unequal development, global health will continue to be 'centred' in high-income countries - and, increasingly, upper middle-income countries, especially China, which has over the last decade transitioned from being a recipient to a major contributor of development assistance for health. ${ }^{26}$ This is because the resources that underpin the field's activities will continue to be provided by governments, philanthropists, private foundations, the corporate sector and individuals situated in richer countries. As funding for global health goals continues to flow from the 'North' (and increasingly the 'East') to the 'South', ensuring proper representation of, respect for, and accountability to, 'Southern' policymakers, researchers and practitioners will remain a complex problem. It is one that can be overcome, or at least offset, but progress will require a properly formulated diagnosis of the problem and an evidence-based theory of change.

Conversely, if the reality of progress is discounted, the space for future improvement is minimised, and only radical, systemic, revolutionary changes are likely to be effective. Thus there are arguments for 'dismantling' global health, for 'flipping every axis of supremacy on its head', for the 'complete overhaul' of the discipline, and for 'anger and revolution', if not violence. ${ }^{3214}$ Criticism of such approaches can be - and has been - dismissed as a mere power play. Yet it may be driven by a genuine concern that these approaches may be damaging in themselves, and impede the creation of broad coalitions needed to deliver sustainable change. ${ }^{3} 1326$

\section{CONCLUSION}

The decolonisation literature is generating additional momentum behind the needed decentralisation of epistemic authority and decision-making power in global health. But analysis that, at least in its more extreme formulations, undermines research-based knowledge, aggravates inter-group and international antagonisms, and disregards the possibility of progress, closes the door to achievable change in an unequal world.

Contributors All authors contributed equally to the drafting, revisions and final approval of this article.

Funding The authors have not declared a specific grant for this research from any funding agency in the public, commercial or not-for-profit sectors.

Competing interests None declared.

Patient consent for publication Not applicable.

Provenance and peer review Not commissioned; externally peer reviewed.

Data availability statement No data are available.

Open access This is an open access article distributed in accordance with the Creative Commons Attribution Non Commercial (CC BY-NC 4.0) license, which permits others to distribute, remix, adapt, build upon this work non-commercially, and license their derivative works on different terms, provided the original work is properly cited, appropriate credit is given, any changes made indicated, and the use is non-commercial. See: http://creativecommons.org/licenses/by-nc/4.0/.

\section{ORCID iDs}

Mark Hellowell http://orcid.org/0000-0003-3474-2080

Patricia Nayna Schwerdtle http://orcid.org/0000-0002-3045-3145

\section{REFERENCES}

1 Büyüm AM, Kenney C, Koris A, et al. Decolonising global health: if not now, when? BMJ Glob Health 2020;5:e003394.

2 Abimbola S, Asthana S, Montenegro C, et al. Addressing power asymmetries in global health: imperatives in the wake of the COVID-19 pandemic. PLoS Med 2020;18:e1003604.

3 Hirsch LA. Is it possible to decolonise global health institutions? The Lancet 2021;397:189-90.

4 Hommes F, Brazal Monzó H, Abbas Ferrand R. The words we choose matter: recognising the importance of language in decolonising global health. The Lancet 2020;9:e897-8.

5 Khan M, Abimbola S, Aloudat T, et al. Decolonising global health in 2021: a roadmap to move from rhetoric to reform. BMJ Glob Health 2021;6:e005604.

$6 \mathrm{Kim} \mathrm{H}$. The implicit ideological function of the global health field and its role in maintaining relations of power. BMJ Glob Health 2021;6:e005620.

7 Ford CL, Airhihenbuwa CO. The public health critical race methodology: praxis for antiracism research. Soc Sci Med 2010;71:1390-8.

8 Yam EA, Silva M, Ranganathan M, et al. Time to take critical race theory seriously: moving beyond a colour-blind gender lens in global health. Lancet Glob Health 2021;9:e389-90.

9 Fanon F. Black skin, white masks (trans. Charles Lam Markmann. New York: Grove, 1967: 109-98.

10 Said E. Culture and imperialism. London: Chatto \& Windus, 1993: 306-14.

11 Abraham S, Hodgins S, Saad A, et al. What Is Global Health: Science and Practice Doing to Address Power Imbalances in Publishing? Glob Health Sci Pract 2020;8:325-6.

12 Abimbola S, Pai M. Will global health survive its decolonisation? Lancet 2020;396:1627-8.

13 Oti SO, Ncayiyana J. Decolonising global health: where are the southern voices? BMJ Glob Health 2021;6:e006576.

14 Chaudhuri MM, Mkumba L, Raveendran Y, et al. Decolonising global health: beyond 'reformative' roadmaps and towards decolonial thought. BMJ Glob Health 2021;6:e006371.

15 Gautier L, Sieleunou I, Kalolo A. Deconstructing the notion of "global health research partnerships" across Northern and African contexts. BMC Med Ethics 2018;19:13-20.

16 de Campos TC. Guiding principles of global health governance in times of pandemics: solidarity, subsidiarity, and stewardship in COVID-19. Am J Bioeth 2020;20:212-4.

17 Abimbola S. The uses of knowledge in global health. BMJ Glob Health 2021;6:e005802.

18 Svadzian A, Vasquez NA, Abimbola S, et al. Global health degrees: at what cost? BMJ Glob Health 2020;5:e003310.

19 Besson EK. Confronting whiteness and decolonising global health institutions. Lancet 2021;397:2328-9. 
20 Richardson ET. Pandemicity, COVID-19 and the limits of public health 'science'. BMJ Glob Health 2020;5:e002571.

21 Rauch J. The constitution of knowledge Rauch. Brookings Institution Press.

22 Ssemugabo C, Choonara S. Global health diplomacy failures in the COVID-19 era: surviving Denialism and corruption in sub-Saharan Africa. Blog. Available: https://blogs.bmj.com/bmjgh/2021/03/20/ global-health-diplomacy-failures-in-the-covid-19-era-survivingdenialism-and-corruption-in-sub-saharan-africa/
23 Affun-Adegbulu C, Adegbulu O. Decolonising global (public) health: from Western universalism to global pluriversalities. BMJ Glob Health 2020;5:e002947.

24 Richardson ET. Epidemic illusions: on the coloniality of global public health. Cambridge: MIT Press, 2002.

25 Sen A. Why health equity? Health Econ 2002;11:659-66.

26 The Global Fund. Data explorer: free and open access to the global fund data, 2021. Available: https://data.theglobalfund.org/ 